\title{
Isolation and Structural Characterization of a New Minor Penta $\beta$-D-Glucopyranosyl Diterpene from Stevia rebaudiana Bertoni
}

\author{
Venkata Sai Prakash Chaturvedula \\ Wisdom Natural Brands, Gilbert, AZ, USA \\ Email: sprakash@wisdomnaturalbrands.com
}

Received 1 October 2014; revised 30 October 2014; accepted 8 November 2014

Academic Editor: Hideaki Otsuka, Faculty of Pharmacy, Yasuda Women's University, Japan

Copyright (C) 2014 by author and Scientific Research Publishing Inc.

This work is licensed under the Creative Commons Attribution International License (CC BY). http://creativecommons.org/licenses/by/4.0/

(c) (;) Open Access

\begin{abstract}
From the commercial extract of the leaves of Stevia rebaudiana Bertoni, a new minor ent-kaurane diterpene glycoside having five $\beta$-D-glucopyranosyl units has been isolated. The chemical structure of the new compound was characterized as 13-[(2-0- $\beta$-D-glucopyranosyl- $\beta$-D-glucopyranosyl)oxy] ent-kaur-16-en-19-oic acid-(2-O- $\beta$-D-glucopyranosyl-6- $O$ - $\beta$-D-glucopyranosyl- $\beta$-D-glucopyranosyl) ester (1) on the basis of extensive 1D $\left({ }^{1} \mathrm{H} \&{ }^{13} \mathrm{C}\right)$ and 2D NMR (TOCSY, HMQC, and HMBC), and High Resolution (HR) mass spectroscopic data as well as hydrolysis studies.
\end{abstract}

\section{Keywords}

Stevia rebaudiana, Compositae, Asteraceae, Diterpenoid Glycoside, Spectral Data, Hydrolysis Studies, Structure Characterization

\section{Introduction}

Stevia rebaudiana (Bertoni) Bertoni is a perennial shrub of the Asteraceae (Compositae) family native to Paraguay and Brazil; often referred to as "the sweet herb of Paraguay" [1]. The major constituents in the leaves of $S$. rebaudiana are the potently sweet diterpene glycosides stevioside, and rebaudioside A; which are known as Stevia sweeteners. All the isolated diterpene glycosides from $S$. rebaudiana are having the aglycone moiety as steviol (ent-13-hydroxykaur-16-en-19-oic acid) [2] [3].

As a part of our research to discover natural sweeteners and their potential usage into food and beverage industry; we have collected commercial extracts of $S$. rebaudiana from various suppliers all over the world and in the process of isolating minor novel diterpene glycosides. Apart from isolating novel compounds from S. rebau- 
diana and utilizing them as possible natural sweeteners or sweetness enhancers, we are also engaged in developing analytical methods for separation of steviol glycosides present in trace quantities in the original S. rebaudiana extract [4]. In this paper, we are describing the isolation and structure elucidation of a minor new diterpenoid glycoside, 13-[(2-O- $\beta$-D-glucopyranosyl- $\beta$-D-glucopyranosyl)oxy] ent-kaur-16-en-19-oic acid-(2-O- $\beta$-Dglucopyranosyl-6-O- $\beta$-D-glucopyranosyl- $\beta$-D-glucopyranosyl) ester (1) based on extensive spectroscopic (NMR and MS) and hydrolysis studies (Figure 1), and in comparison with the spectral data of the two known steviol glycosides rebaudioside E (2) [5], and rebaudioside M2 (3) [6].

\section{Experimental}

\subsection{General Instrumentation}

An Agilent (Wilmington, DE) 1100 HPLC System, including a quaternary pump, a temperature controlled column compartment with an additional 6 port switching valve, an auto sampler and VWD absorbance detector was used for analysis. The detector was set-up at UV $210 \mathrm{~nm}$ and the data acquisition was done using a Chemastation A 10.02 software. The column used for HPLC analysis was a reversed-phase C18 (2) 100 A Phenomenex (Torrance CA) $(250 \times 4.6 \mathrm{~mm}, 5 \mu \mathrm{m})$; $\mathrm{pH}$ was measured using meter Metler Toledo seven compact pH/ion S220 (Switzerland); Branson Ultrasonic Cleaner Model 2510 (Maplewood, NJ) was used for degassing HPLC solvents. NMR spectra were acquired on BrukerAvance DRX $500 \mathrm{MHz}$ or Varian INOVA $600 \mathrm{MHz}$ instrument instruments using standard pulse sequences. High Resolution Mass Spectral (HRMS) data were generated with a LTQ Orbitrap Discovery instrument with its resolution set to $30 \mathrm{k}$. The needle voltage was set to $4 \mathrm{kV}$; the other source conditions were sheath gas $=25$, aux gas $=0$, sweep gas $=5$ (all gas flows in arbitrary units), capillary voltage $=30 \mathrm{~V}$, capillary temperature $=300^{\circ} \mathrm{C}$, and tube lens voltage $=75$. Sample was diluted with 2:2:1 $\mathrm{CH}_{3} \mathrm{CN}: \mathrm{MeOH}$ :water (same as infusion eluent) and injected 50 microliters. TLC was performed on Baker Si$\mathrm{C}_{18} \mathrm{~F}$ plates with mobile phase $\mathrm{H}_{2} \mathrm{O}-\mathrm{MeOH}(80: 20)$. Identification of the spots on the TLC plate was carried out by spraying $10 \% \mathrm{H}_{2} \mathrm{SO}_{4}$ in $\mathrm{EtOH}$ and heating the plate at about $80 \mathrm{C}$.

\subsection{Plant Material}

The commercial sample of Stevia extract from the leaves of S. rebaudiana which is a mixture of diterpene glycosides was obtained from Sinochem Qingdao Co Ltd, China with Lot No: 20140611. The authenticity of the commercial extract was confirmed by performing its retention time $\left(t_{R}\right)$ comparison with the internal standard compounds of known JECFA steviol glycosides isolated from $S$. rebaudiana using the HPLC method as reported earlier [7]. A voucher specimen is deposited at Wisdom Natural Brands.

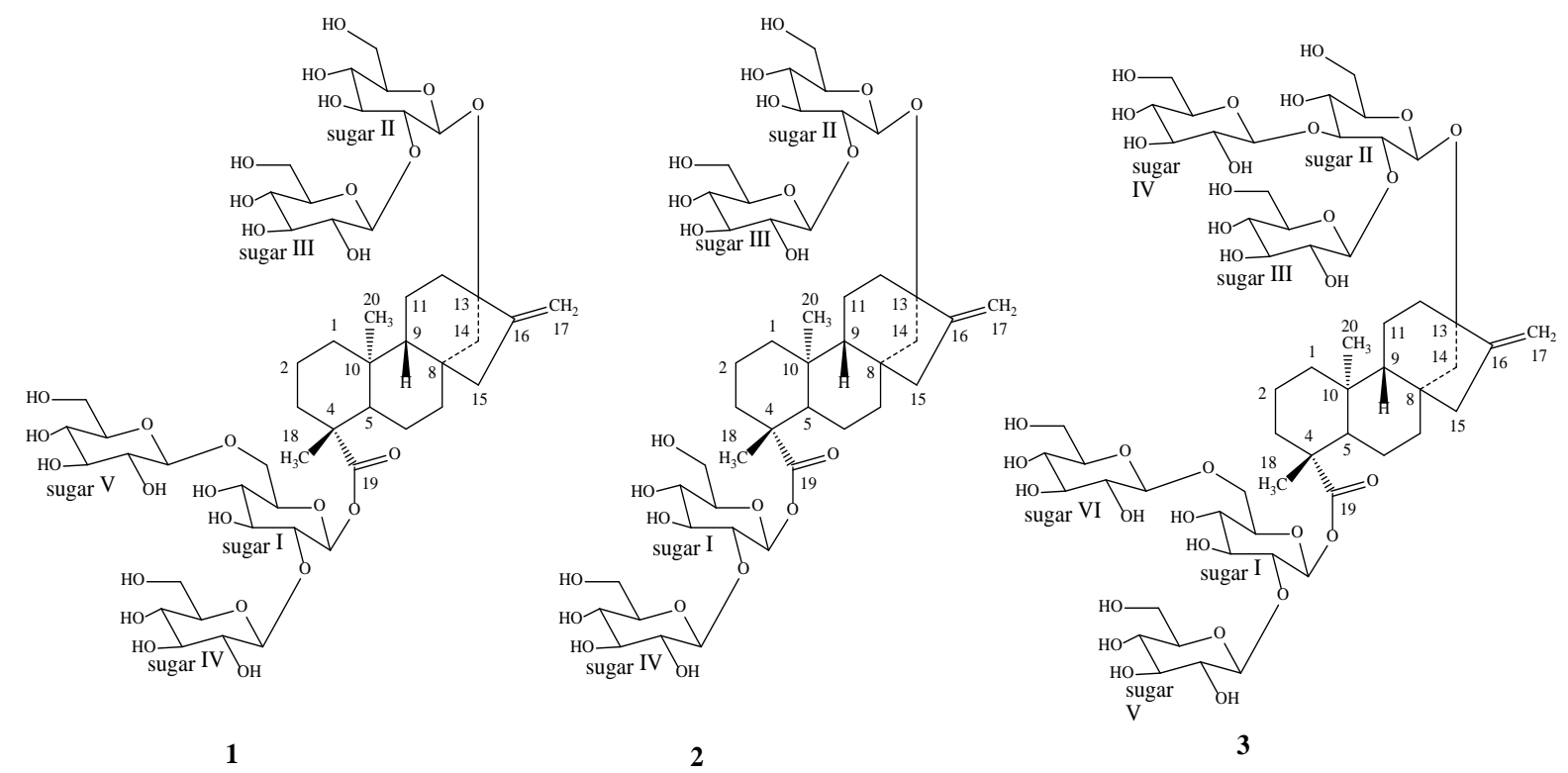

Figure 1. Structures of compounds 1-3. 
2.3. Isolation and Purification of $13-[(2-0-\beta$-D-glucopyranosyl- $\beta$-D-glucopyranosyl)oxy] ent-kaur-16-en-19-oic acid-(2-0- $\beta$-D-glucopyranosyl-6-0- $\beta$-D-glucopyranosyl- $\beta$-D-glucopyranosyl) ester (1)

Compound 1 was purified from the commercial Stevia extract obtained from Sinochem Qingdao Co. Ltd., China using an Agilent 1100 HPLC system with Phenomenex column $(250 \times 4.6 \mathrm{~mm}, 5 \mu \mathrm{m})$ by RP-HPLC in 3 stages. The first stage utilized an isocratic elution method using the mobile phase acetonitrile/phosphate buffer (20:80); flow rate: $2 \mathrm{~mL} / \mathrm{min}$; injection volume: $50 \mu \mathrm{L}$; detection: $210 \mathrm{~nm}$. The eluent collected between $t \mathrm{R} 8.0$ and 9.5 min has been combined over several runs; dried the corresponding solution under nitrogen yielded a mixture (12.4 mg), which on second stage of purification with an isocratic mobile phase acetonitrile/phosphate buffer (25:75); flow rate: $1 \mathrm{~mL} / \mathrm{min}$; injection volume: $10 \mu \mathrm{L}$; detection: $210 \mathrm{~nm}$.. The eluent collected between $t \mathrm{R} 12.0$ and 14.0 min has been combined over several runs; dried the corresponding solution under nitrogen yielded a mixture (8.4 mg), which on final stage of purification with an isocratic mobile phase acetonitrile/phosphate buffer (32:68); flow rate: $0.5 \mathrm{~mL} / \mathrm{min}$; injection volume: $10 \mu \mathrm{L}$; detection: $210 \mathrm{~nm}$. The peak eluting at $t \mathrm{R} 16.24$ $\mathrm{min}$ has been collected over multiple runs; dried the corresponding solution under nitrogen yielded $\mathbf{1}$ (2.4 mg).

Identification and spectroscopic data of Compound 1. White powder; ${ }^{1} \mathrm{H}$ NMR $\left(600 \mathrm{MHz}, \mathrm{C}_{5} \mathrm{D}_{5} \mathrm{~N}, \delta \mathrm{ppm}\right)$ and ${ }^{13} \mathrm{C}$ NMR (150 MHz, $\mathrm{C}_{5} \mathrm{D}_{5} \mathrm{~N}, \delta$ ppm) spectroscopic data see Table 1; HRMS $(\mathrm{M}+\mathrm{Na})^{+} \mathrm{m} / \mathrm{z} 1151.4717$ (calcd. for $\mathrm{C}_{50} \mathrm{H}_{80} \mathrm{O}_{28} \mathrm{Na}$ : 1151.4734).

Table 1. ${ }^{1} \mathrm{H}$ and ${ }^{13} \mathrm{C}$ NMR spectral data (chemical shifts and coupling constants) of $\mathbf{1}$ in d5-pyridine $\left(\mathrm{C}_{5} \mathrm{D}_{5} \mathrm{~N}\right)^{\mathrm{a}-\mathrm{c}}$.

\begin{tabular}{|c|c|c|}
\hline Position & ${ }^{1} \mathrm{H}$ NMR & ${ }^{13} \mathrm{C}$ NMR \\
\hline 1 & $0.75 \mathrm{t}(12.4), 1.72 \mathrm{~m}$ & 41.4 \\
\hline 2 & $1.46 \mathrm{~m}, 2.21 \mathrm{~m}$ & 20.3 \\
\hline 3 & $1.02 \mathrm{~m}, 2.40 \mathrm{~d}(12.3)$ & 38.6 \\
\hline 4 & --- & 45.0 \\
\hline 5 & $1.00 \mathrm{~d}(10.8)$ & 58.0 \\
\hline 6 & $1.87 \mathrm{~m}, 2.10 \mathrm{~m}$ & 22.6 \\
\hline 7 & $1.26 \mathrm{~m}, 134 \mathrm{~m}$ & 42.2 \\
\hline 8 & --- & 43.2 \\
\hline 9 & $0.86 \mathrm{~d}(7.2)$ & 54.7 \\
\hline 10 & --- & 40.1 \\
\hline 11 & $1.68 \mathrm{~m}$ & 21.2 \\
\hline 12 & $1.96 \mathrm{~m}, 2.24 \mathrm{~m}$ & 37.9 \\
\hline 13 & --- & 87.0 \\
\hline 14 & $1.78 \mathrm{~d}$ (10.8), $2.67 \mathrm{~d}(11.3)$ & 44.7 \\
\hline 15 & $1.34 \mathrm{~m}, 2.06 \mathrm{~m}$ & 48.4 \\
\hline 16 & --- & 154.8 \\
\hline 17 & $5.05 \mathrm{~s}, 5.66 \mathrm{~s}$ & 105.2 \\
\hline 18 & $1.40 \mathrm{~s}$ & 28.8 \\
\hline 19 & --- & 176.4 \\
\hline 20 & $1.12 \mathrm{~s}$ & 17.1 \\
\hline $1^{\prime}$ & $6.32 \mathrm{~d}(7.8)$ & 94.0 \\
\hline $2^{\prime}$ & $4.34 \mathrm{~m}$ & 81.4 \\
\hline
\end{tabular}




\section{Continued}

\begin{tabular}{|c|c|c|}
\hline $3^{\prime}$ & $4.18 \mathrm{~m}$ & 78.7 \\
\hline $4^{\prime}$ & $4.26 \mathrm{~m}$ & 72.2 \\
\hline $5^{\prime}$ & $4.08 \mathrm{~m}$ & 78.6 \\
\hline $6^{\prime}$ & $4.42 \mathrm{~m}, 4.62 \mathrm{~m}$ & 70.2 \\
\hline $1^{\prime \prime}$ & $5.14 \mathrm{~d}(7.4)$ & 98.4 \\
\hline $2^{\prime \prime}$ & $4.18 \mathrm{~m}$ & 84.6 \\
\hline $3^{\prime \prime}$ & $4.32 \mathrm{~m}$ & 78.8 \\
\hline $4^{\prime \prime}$ & $4.24 \mathrm{~m}$ & 71.8 \\
\hline $5^{\prime \prime}$ & $3.80 \mathrm{~m}$ & 78.9 \\
\hline $6^{\prime \prime}$ & $4.26 \mathrm{~m}, 4.41 \mathrm{~m}$ & 63.0 \\
\hline $1^{\prime \prime \prime}$ & $5.22 \mathrm{~d}(7.8)$ & 107.0 \\
\hline $2^{\prime \prime \prime}$ & 4.14 t (8.4) & 77.6 \\
\hline $3^{\prime \prime \prime}$ & $4.25 \mathrm{~m}$ & 78.7 \\
\hline $4^{\prime \prime \prime}$ & $4.34 \mathrm{~m}$ & 72.4 \\
\hline $5^{\prime \prime \prime}$ & $3.94 \mathrm{~m}$ & 79.1 \\
\hline $6^{\prime \prime \prime}$ & $4.29 \mathrm{~m}, 4.45 \mathrm{~m}$ & 63.3 \\
\hline $1^{\prime \prime \prime \prime}$ & $5.48 \mathrm{~d}(7.5)$ & 106.0 \\
\hline $2^{\prime \prime \prime \prime}$ & $4.07 \mathrm{~m}$ & 77.2 \\
\hline $3^{\prime \prime \prime \prime}$ & $4.18 \mathrm{~m}$ & 79.1 \\
\hline $4^{\prime \prime \prime \prime \prime}$ & $4.32 \mathrm{~m}$ & 71.5 \\
\hline $5^{\prime \prime \prime \prime}$ & $3.96 \mathrm{~m}$ & 79.3 \\
\hline $6^{\prime \prime \prime \prime}$ & $4.16 \mathrm{~m}, 4.38 \mathrm{~m}$ & 63.6 \\
\hline $1^{\prime \prime \prime \prime \prime \prime}$ & $5.06 \mathrm{~d}(7.5)$ & 106.4 \\
\hline $2^{\prime \prime \prime \prime \prime \prime}$ & $4.04 \mathrm{~m}$ & 77.2 \\
\hline $3^{\prime \prime \prime \prime \prime \prime}$ & $4.18 \mathrm{~m}$ & 78.8 \\
\hline $4^{\prime \prime \prime \prime \prime \prime}$ & $4.28 \mathrm{~m}$ & 72.0 \\
\hline $5^{\prime \prime \prime \prime \prime \prime}$ & $4.02 \mathrm{~m}$ & 79.2 \\
\hline $6^{\prime \prime \prime \prime \prime}$ & $4.32 \mathrm{~m}, 4.43 \mathrm{~m}$ & 63.4 \\
\hline
\end{tabular}

${ }^{\mathrm{a}}$ Assignments made on the basis of TOCSY, HMQC and HMBC correlations; ${ }^{\mathrm{b}}$ Chemical shift values are in $\delta$ (ppm); ${ }^{\mathrm{c} C o u p l i n g}$ constants are in Hz.

Acid Hydrolysis of 1. Compound $1(500 \mu \mathrm{g})$ is dissolved in $\mathrm{MeOH}(3 \mathrm{ml})$ and added $5 \% \mathrm{H}_{2} \mathrm{SO}_{4}(10 \mathrm{~mL})$. The mixture was refluxed for 16 hours and then neutralized with saturated sodium carbonate after cooling to room temperature. The aqueous phase was extracted with ethyl acetate (EtOAc, $2 \times 15 \mathrm{ml}$ ) to separate an EtOAc fraction containing the aglycone part. The aqueous layer was concentrated and compared with standard sugars using the TLC system EtOAc/n-butanol/water (2:7:1) and $\mathrm{CH}_{2} \mathrm{Cl}_{2} / \mathrm{MeOH} /$ water (10:6:1) [8]-[10]; the sugars were identified as glucose.

Enzymatic hydrolysis of 1. Compound $1(500 \mu \mathrm{g})$ was dissolved in $5.0 \mathrm{~mL}$ of $0.1 \mathrm{M}$ sodium acetate buffer ( $\mathrm{pH}$ 4.5) and crude pectinase from Aspergillusniger (250 $\mu \mathrm{L}$, Sigma-Aldrich, P2736) was added. The mixture was stirred at $50^{\circ} \mathrm{C}$ for $48 \mathrm{hr}$. The product precipitated out during the reaction was filtered and then purified using reversed-phase preparative TLC using water:MeOH (70:30) yielded a pure compound, which was identified as steviol by comparison with co-TLC and ${ }^{1} \mathrm{H}-\mathrm{NMR}$ of an authentic sample as well as from the spectral data 
from the literature [11].

\section{Results and Discussion}

The molecular formula of compound $\mathbf{1}$ has been deduced as $\mathrm{C}_{50} \mathrm{H}_{80} \mathrm{O}_{28}$ on the basis of its positive high resolution (HR) mass spectrum which showed an ion corresponding to $[\mathrm{M}+\mathrm{Na}]^{+}$at $m / z$ 1151.4717; this composition was supported by the ${ }^{13} \mathrm{C}$ NMR spectral data. The ${ }^{1} \mathrm{H}$ NMR spectral data of $\mathbf{1}$ showed the presence of two methyl singlets at $\delta 1.12$ and 1.40, two olefinic protons as singlets at $\delta 5.05$ and 5.66 of an exocyclic double bond, nine sp3 methylene and two sp3 methine protons between $\delta 0.75$ - 2.67, characteristic for the ent-kaurane diterpenoids isolated earlier from the genus Stevia [12]-[15]. The basic skeleton of ent-kaurane diterpenoids was supported by the TOCSY studies which showed key correlations: H-1/H-2; H-2/H-3; H-5/H-6; H-6/H-7; H-9/H-11; $\mathrm{H}-11 / \mathrm{H}-12$. Acid hydrolysis of $\mathbf{1}$ with $5 \% \mathrm{H}_{2} \mathrm{SO}_{4}$ afforded D-glucose which was identified by direct comparison with authentic sample by TLC [8]-[10]. The ${ }^{1} \mathrm{H}$ NMR spectrum of $\mathbf{1}$ also showed the presence of five anomeric protons resonating at $\delta 5.06,5.14,5.22,5.48$, and 6.32; suggesting five glucopyronosyl units in its structure. The large coupling constants observed for the five anomeric protons of the glucose moieties at $\delta 5.06$ (d, $J=7.5 \mathrm{~Hz})$, 5.14 (d, $J=7.4 \mathrm{~Hz}), 5.22(\mathrm{~d}, J=7.8 \mathrm{~Hz}), 5.48(\mathrm{~d}, J=7.5 \mathrm{~Hz}$ ), and 6.32 (d, $J=7.8 \mathrm{~Hz}$ ), suggested their $\beta$-orientation as reported for steviol glycosides [11]-[15]. The ${ }^{1} \mathrm{H}$ and ${ }^{13} \mathrm{C}$ NMR values for compound $\mathbf{1}$ were assigned on the basis of TOCSY, HMQC and HMBC data and are given in Table 1. Further, the nature of D-glucose units was confirmed by the comparison of the ${ }^{13} \mathrm{C}$ NMR spectral of 1 with known steviol glycosides [8]-[10].

Enzymatic hydrolysis of $\mathbf{1}$ furnished an aglycone which was identified as steviol by comparison of ${ }^{1} \mathrm{H}-\mathrm{NMR}$ and co-TLC with standard compound [11]. Based on the results from NMR spectral data and hydrolysis experiments, the basic skeleton of $\mathbf{1}$ has been deduced as a steviol aglycone with five $\beta$-D-glucosyl units in its structure. A close comparison of the ${ }^{1} \mathrm{H}$ and ${ }^{13} \mathrm{C}$ NMR values of 1 with rebaudioside $\mathrm{E}$ (2) [5] suggested the presence of a steviol aglycone moiety with a 2-O- $\beta$-D-glucobiosyl unit at C-13 in the form of ether linkage and another 2-O$\beta$-D-glucobiosyl unit at C-19 position in the form of an ester linkage, leaving the assignment of the additional $\beta$ D-glucosyl unit. The downfield shift for both the ${ }^{1} \mathrm{H}$ and ${ }^{13} \mathrm{C}$ chemical shifts at 6 -position of sugar I of the $\beta$-Dglucosyl moiety in $\mathbf{1}$ suggested that the additional $\beta$-D-glucosyl unit has been attached at this position, which was supported by the comparison of the ${ }^{1} \mathrm{H}$ and ${ }^{13} \mathrm{C}$ NMR values of rebaudioside M2 [6]. The structure was further supported by the key TOCSY and HMBC correlations as shown in Figure 2.

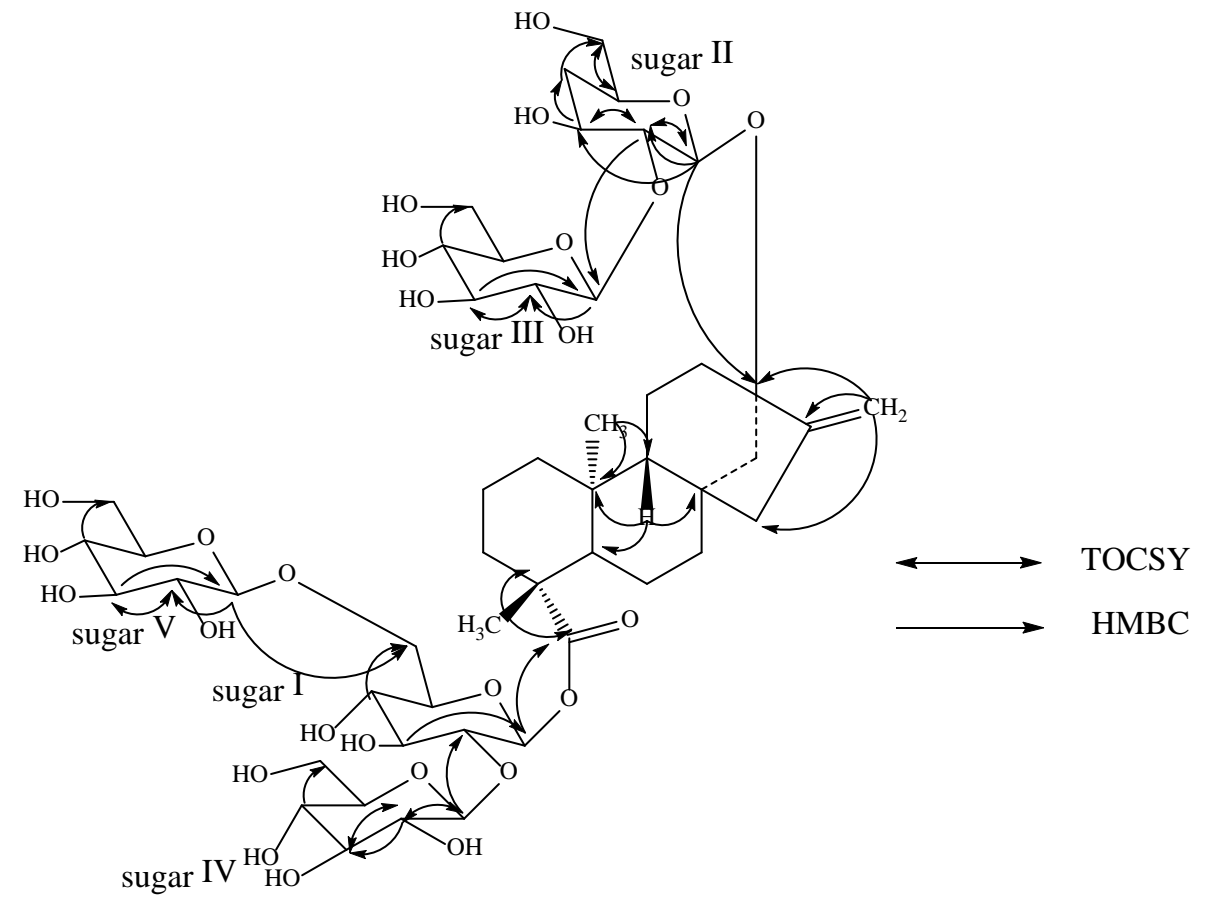

Figure 2. Key TOCSY, and HMBC correlations of 1. 
Based on the results of NMR and mass spectral data as well as hydrolysis studies, the structure of $\mathbf{1}$ was deduced as 13 -[(2-O- $\beta$-D-glucopyranosyl- $\beta$-D-glucopyranosyl)oxy] ent-kaur-16-en-19-oic acid-(2-O- $\beta$-D-glucopyranosyl6 -O- $\beta$-D-glucopyranosyl- $\beta$-D-glucopyranosyl) ester.

\section{Conclusion}

A new diterpenoid glycoside, 13-[(2-O- $\beta$-D-glucopyranosyl- $\beta$-D-glucopyranosyl)oxy] ent-kaur-16-en-19-oic acid-(2-O- $\beta$-D-glucopyranosyl-6-O- $\beta$-D-glucopyranosyl- $\beta$-D-glucopyranosyl) ester (1) has been isolated from the commercial extract of the leaves of S. rebaudiana obtained from Sinochem Qingdao Co. Ltd. (China). The new compound was identified and characterized based on the basis of NMR and HR mass spectral data as well as hydrolysis studies. This is the first report of the isolation of this new diterpene glycoside in nature, which is an important addition in expanding our understanding of the diversity of the diterpenoid glycosides present in the leaves of $S$. rebaudiana and their structure-activity relationship.

\section{Acknowledgements}

Thanks to James May, Chief Executive Officer and Carol May, President of Wisdom Natural Brands for their support. Also, thanks to Department of Chemistry, Emory University, Atlanta, GA and Novatia LLC, Newtown, PA for providing selected NMR and HRMS spectral data respectively.

\section{References}

[1] Brandle, J.E., Starrratt, A.N. and Gijen, M. (1998) Stevia rebaudiana: Its Agricultural, Biological and Chemical Properties. Canadian Journal of Plant Sciences, 78, 527-536. http://dx.doi.org/10.4141/P97-114

[2] Mosettig, S.E. and Nes, W.R. (1955) Stevioside. II. The Structure of the Aglucon. Journal of Organic Chemistry, 20, 884-899. http://dx.doi.org/10.1021/jo01125a013

[3] Mosettig, S.E., Beglinger, U., Dolder, F., Lichiti, H., Quitt, P. and Waters, J.A. (1963) The Absolute Configuration of Steviol and Isosteviol. Journal of American Chemical Society, 85, 2305-2309. http://dx.doi.org/10.1021/ja00898a025

[4] Chaturvedula, V.S.P. and Zamora, J. (2014) Reversed-Phase HPLC Analysis of Steviol Glycosides Isolated from Stevia rebaudiana Bertoni. Food and Nutrition Sciences, 5, 1711-1716. http://dx.doi.org/10.4236/fns.2014.517184

[5] Chaturvedula, V.S.P. and Prakash, I. (2013) Structural Characterization and Hydrolysis Studies of Rebaudioside E, a Minor Sweet Component of Stevia rebaudiana. European Chemical Bulletin, 2, 298-302.

[6] Prakash, I., Bunders, C., Devkota, K.P., Charan, R.D., Ramirez, C., Priedmann, C. and Markosyan, A. (2014) Isolation and Characterization of a Novel Rebaudioside M Isomer from a Bioconversion Reaction of Rebaudioside A and NMR Comparison Studies of Rebaudioside M Isolated from Stevia rebaudiana Bertoni and Stevia rebaudiana Morita. Biomolecules, 4, 374-389. http://dx.doi.org/10.3390/biom4020374

[7] JECFA (2010) Steviol Glycosides [Prepared at the 73rd JECFA (2010) and published in FAO JECFA Monographs 10 (2010)]. In: Combined Compendium of Food Additive Specifications (Online Edition). General Specifications for Enzymes Analytical Methods, Volume 4. (FAO JECFA Monographs 10). Food and Agriculture Organization of the United Nations (FAO), Joint FAO/WHO Expert Committee on Food Additives (JECFA), Rome. http://www.fao.org/ag/agn/jecfa-additives/specs/monograph10/additive-442-m10.pdf

[8] Bedir, E., Toyang, N.J., Khan, I.A., Walker, L.A. and Clark, A.M. (2001) A New Dammarane Type Triterpene Glycoside from Polyscias fulva. Journal of Natural Products, 64, 95-97. http://dx.doi.org/10.1021/np0003589

[9] Chaturvedula, V.S.P., Schilling, J.K., Miller, J.S., Andriantsiferana, R., Rasamison, V.E. and Kingston, D.G.I. (2003) New Cytotoxic Oleanane Saponins from the Infructescences of Polyscias amplifolia from the Madagascar Rainforest. Planta Medica, 69, 440-444. http://dx.doi.org/10.1055/s-2003-39711

[10] Huan, V.D., Yamamura, S., Ohtani, K., Kasai, R., Yamasaki, K. and Nham, N.T. (1998) Oleanane Saponins from Polysciasfructicosa. Phytochemistry, 47, 451-457.http://dx.doi.org/10.1016/S0031-9422(97)00618-3

[11] Ohtani, K., Aikawa, Y., Kasai, R., Chou, W., Yamasaki, K. and Tanaka, O. (1992) Minor Diterpene Glycosides from Sweet Leaves of Rubus suavissimus. Phytochemistry, 31, 1553-1559. http://dx.doi.org/10.1016/0031-9422(92)83105-8

[12] Chaturvedula, V.S.P., Mubarak, C. and Prakash, I. (2012) IR Spectral Analysis of Diterpene Glycosides of Stevia rebaudiana. Food and Nutrition Sciences, 3, 1467-1471. http://dx.doi.org/10.4236/fns.2012.310191

[13] Chaturvedula, V.S.P., Chen, S., Yu, O. and Mao, G. (2013) NMR Spectral Analysis and Hydrolysis Studies of Rebaudioside N, a Minor Steviol Glycoside of Stevia rebaudiana Bertoni. Food and Nutrition Sciences, 4, 1004-1008. http://dx.doi.org/10.4236/fns.2013.410130 
[14] Chaturvedula, V.S.P. and Prakash, I. (2011) A New Diterpenoid Glycoside from Stevia rebaudiana. Molecules, 16, 2937-2943. http://dx.doi.org/10.3390/molecules16042937

[15] Chaturvedula, V.S.P. and Prakash, I. (2011) Structures of the Novel Diterpene Glycosides from Stevia rebaudiana, Carbohydrate Research, 346, 1057-1060. http://dx.doi.org/10.1016/j.carres.2011.03.025 
Scientific Research Publishing (SCIRP) is one of the largest Open Access journal publishers. It is currently publishing more than 200 open access, online, peer-reviewed journals covering a wide range of academic disciplines. SCIRP serves the worldwide academic communities and contributes to the progress and application of science with its publication.

Other selected journals from SCIRP are listed as below. Submit your manuscript to us via either submit@scirp.org or Online Submission Portal.
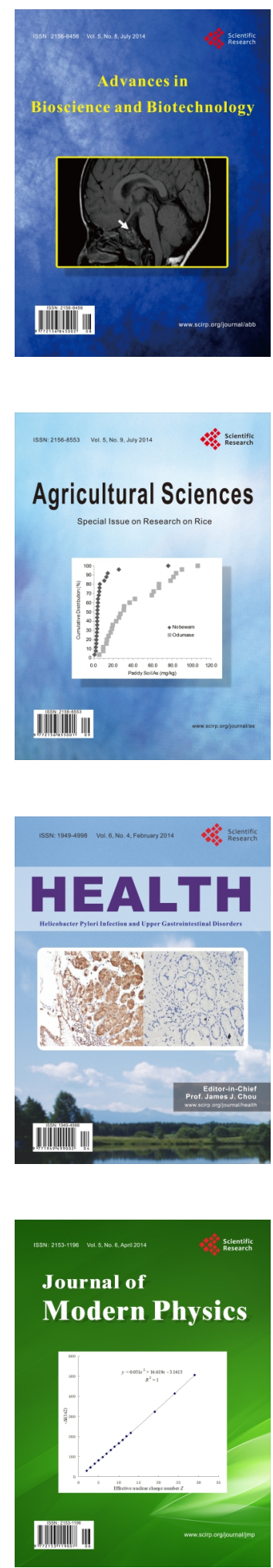
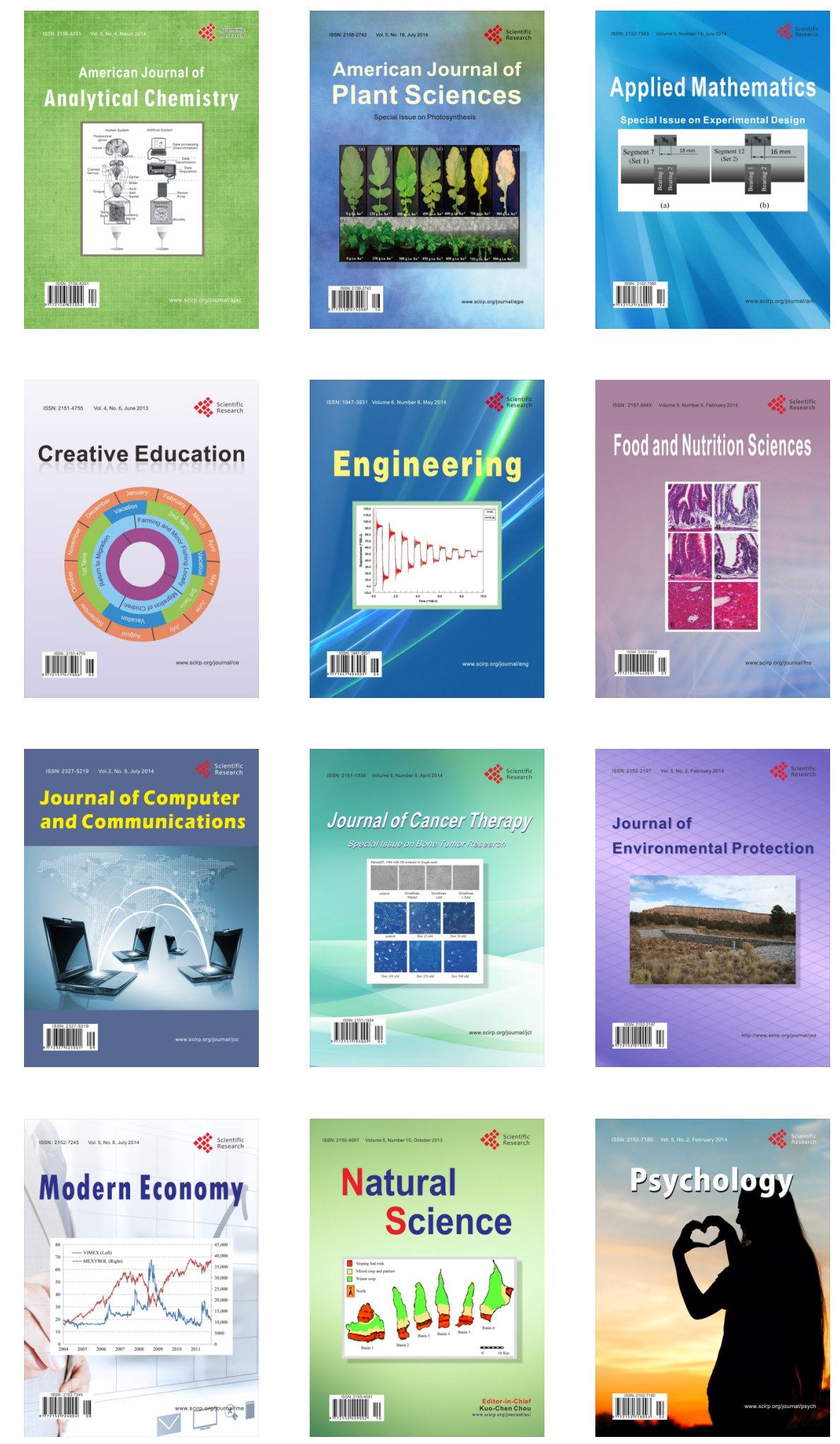